beds which overlie the great mass of the midland Carboniferous Limestone.

For the next two chapters we have nothing but commendation. They deal with the time represented by the great gap between the CuIm and the Permian rocks. The first is entitled "The Great Upheaval," and gives a clear and sufficient account of the postCarboniferous mountain-ranges which are known as the Hercynian or Armorican system, and of the subsidiary Pennine range. This is illustrated by a restoration of the physical geography of the British area at this time. The succeeding chapter is devoted to volcanic rocks, with especial regard to the Carboniferous and post-Carboniferous volcanoes.

In the discussion of the Dartmoor granite in chapter vii. the author is faced by a problem which has given rise to many diverse expressions of opinion. $\mathrm{He}$ practically adopts the view advocated by the late R. N. Worth, and sets himself to show "that the granite mass of Dartmoor is really the solidified upper part of the cooled lava reservoir from which the Carboniferous volcanoes of Devon were fed." We think he states the case for this theory with somewhat of over-confidence, for the dissolving of sedimentary rock in the granitic magma is thought by some to be very improbable, and the temperature at which the granite solidified is still a disputed point, while the actual evidence for the existence of volcanoes over the Dartmoor granite is by no means strong. Prominence is, of course, given to the occurrence of peculiar volcanic rocks in the Permian breccias, the origin of which is also dealt with in this chapter.

In the chapter on the "Salt Lake Period" (chapter viii.), an excellent account is given of the Devon Trias and of the conditions under which its successive beds were deposited, the proofs of its salinity and of its barren desert-surroundings being well brought out. The illustrations, too, are especially good, including photographs of "red marl with salt-crystals," "the base of the Budleigh pebble-bed," and " the teagreen marls overlain by the Rhætic bone-bed."

The dawn of Jurassic time and the great climatic change produced by the irruption of the sea into the salt lake are set forth in the opening page of a chapter entitled "The Age of Reptiles." In this the Lias and the Liassic sea are duly described, and the subsequent sequence of Jurassic rocks is briefly indicated, with some remarks on the erosion to which the surrounding land must have been exposed during the whole period, and especially during its closing scenes, when the British area was again upraised, and the sea retreated far to the south and north-east.

Under the title "The Return of the Sea," chapter $\mathrm{x}$. deals with the beginning of the great Cretaceous subsidence. The stratigraphy of the Gault and Greensand is briefly but clearly described, and there are excellent views of the two cliff sections near Seaton Haven cliff and Whitecliff, the former of which we have selected as an example. Then follows a chapter on "The Chalk," in which the peculiar Devon development of an arenaceous Cenomanian overlain by Middle Chalk and a portion of the Upper Chalk is fairly well described. We notice, however, that there is no mention of the "Beer Stone," another Devon speciality, which differs greatly from ordinary chalk and has been largely used as a building stone from Norman times to the present day.

Mr. Clayden appears to be unaware of the views published in the Geological Survey memoir on the
Cretaceous rocks of Britain respecting the physical conditions under which the different parts of the Chaik were accumulated. When, therefore, he observes that the facts " are inconsistent with the idea of a deep sea," and assumes that the Chalk (as a whole!) was formed "in a shallow sea perhaps less than 100 fathoms deep," we can only express our surprise.

Chapters xii. and xiii. deal with Eocene time, describing the "Plateau Gravels" and the Bovey deposits, which latter the author considers to be essentially lacustrine, and to have been formed in " the Bovey lake." Chapter xiv., entitled "The Rivers of Devon," is the most original portion of the book, and we only wish that the author had developed this subject at greater length. When we say that he believes the drainage of the whole of northern and central Devon in early Tertiary time to have been carried off by one great river flowing eastward, it will be obvious that such a supposition raises many interesting questions. We are inclined to regard it as a very probable theory, but undoubtedly its details require fuller consideration than he gives them.

The modern scenery of the county, how it is partly an uncovered Permian surface and partiy one carved out of an Eocene peneplain, is briefly described in the

.

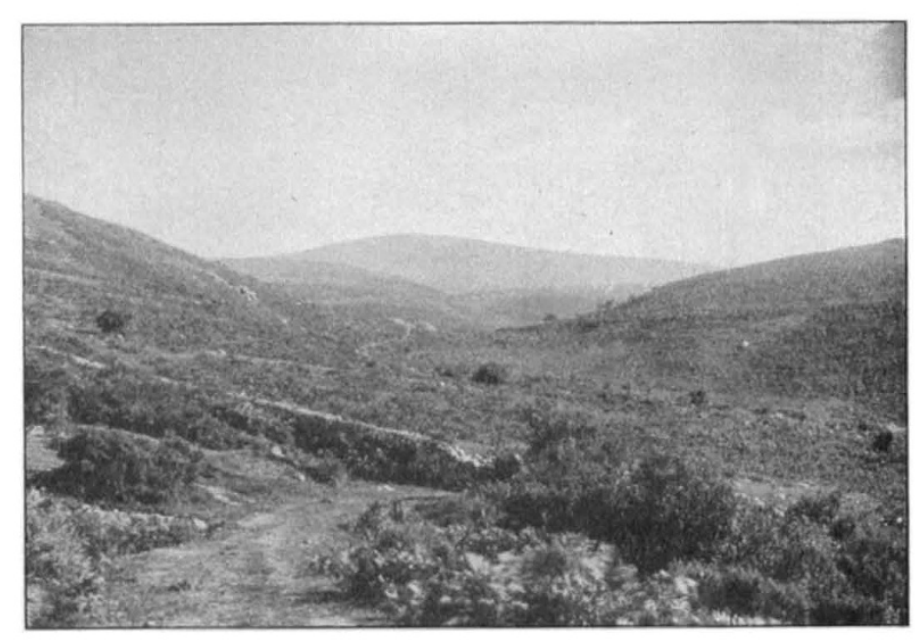

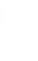

Fig. 2.-The Crown of the Moor : Yes Tor. From "The History of Devonshire Scenery."

final chapter. Dartmoor also comes in for further mention, and its type of scenery is well illustrated, as will be seen from the illustration selected.

In conclusion it may be said that $\mathrm{Mr}$. Clayden has succeeded very well in the accomplishment of his general intention. The book appeals to a much wider circle than the few readers who may be found in Devon and Cornwall. It really treats of the whole of southern England from Dover to Bude, and should be in the hands of all those who are interested in the geology and the physical geography of our southern counties.

\section{THE UNCIVILISED CHILD.'}

"T $\mathrm{HE}$ explanation is rather artistic than scientific"--so the author admits about what he has written on the origin of the "couvade." It is a way of saying that he has found his explanation does not accord with the facts gathered by anthropologists concerning this custom. Such is the keynote of the

1 "Savage Childhood: a Study of Kafir Children." By! Dudley Kidन. Pp. xvi + 3r4. (London: Adam and Charles Black, 1906.) Price $75.6 d$. net.

$$
\text { NO. 1936, vol. 75] }
$$


book : it is artistic rather than scientific. It is a lifehistory of the Kafir child, an excellent record of many facts concerning customs, practices, games, songs, sayings; and it may be particularly commended for the number of capital photographs which illustrate it. But the scientific possibilities in all this field of observation have been practically untouched. The Kafir baby has not been studied from the Darwinian standpoint, the superstitions which affect him have hardly been looked at with the folklorist's knowledge, racial customs and practices have scarcely been viewed in the light of anthropology.

One must have expected to find in savage children many instances of those Simian characters which have been noted among European children; even-because the Kafir child is on a lower scale--to find them more pronounced. But the author says nothing about them, and his photographs give very little in this way. One picture-it is the frontispiece in the book-show's a shy child, who has instinctively assumed an attitude of self-defence, and has its arm raised as if to ward off a blow, and especially to protect the eyes. Now, as fear is the natural basis of shyness, this attitude is very happy. It is an inherited instinct, no doubt, but not necessarily Simian; yet if the author had been on the watch for exhibitions of inherited instinct he would certainly have obtained many which were truly Simian in their origin.

Had the author been more fully acquainted with folklore results he would not show so many doubts about accounting for various customs. For instance, he notices (pp. 41, 42) the practice of a Kafir mother protecting her child by leaving a ring of her milk round it, or by squeezing " a few drops of her milk on to its head." He suggests two explanations; but from folklore research he could learn that the second is more nearly correct-that the milk forms a connecting link with the mother; or, rather, that the milk is actually the mother herself present. As $\mathrm{Mr}$. Hartland says in discussing the life-token, "the external object is believed to be, or to contain, a part of the man himself " ("Legend of Perseus," ii., p. 5I). The word "part" there is hardly sufficient. The external object, the detached portion of a person, or anything which has absorbed a portion of a person, is believed to be more than a part: it is rather looked on as the alter ego, subject to all his disabilities, endowed with all his potentialities; and just as destruction of the alter ego involves destruction of the ego, the very basis of witchcraft, so the power to watch and ward, which the ego possessed, is supposed to be also inherent in the alter ego. The mother's milk is as capable a protector as the mother herself.

The basis of the same superstition-that a part of self is the other self-is further illustrated by the author in "Confusion of Self with the Clothing and Possessions," "with the Shadow," "with the Picture," "with the Name," and so on (pp. 66 et seqq.); and he gives quite the right explanation of these. The man's shadow is but another form of himself, and anything done to his shadow is done to him. The "native doctors apply medicine to people's shadows as well as to their bodies" (p. 7o), that is, application to the shadow is quite as efficacious as to the body. So a man refused to be photographed; because the person having the photograph would have a hold on him (p. $7 \mathrm{I})$.

The secret burning of the child's sleeping mat (p. 84) is another case. The mat is burnt to prevent it falling into the hands of any evil-disposed person, who could then work ill on the child. Here we have the apparent contradiction that meets us in such customs. One would at first think that the destruction of the mat would mean the killing of the child. So it would, if done with evil intent; because the intention with which an action is done makes all the difference.

To conclude, one may quote some admirable remarks of the author on the unfortunate result of ignorant European interference with Kafir customs. When it is considered how terrible a failure individualistic civilisation is, at any rate for some millions of our population, and that the remedy is declared to be Socialism, it is quite possible to echo the author's protest against forcing individualism on people who appear to have got great enjoyment out of life under Socialism. The author says (p. I29),

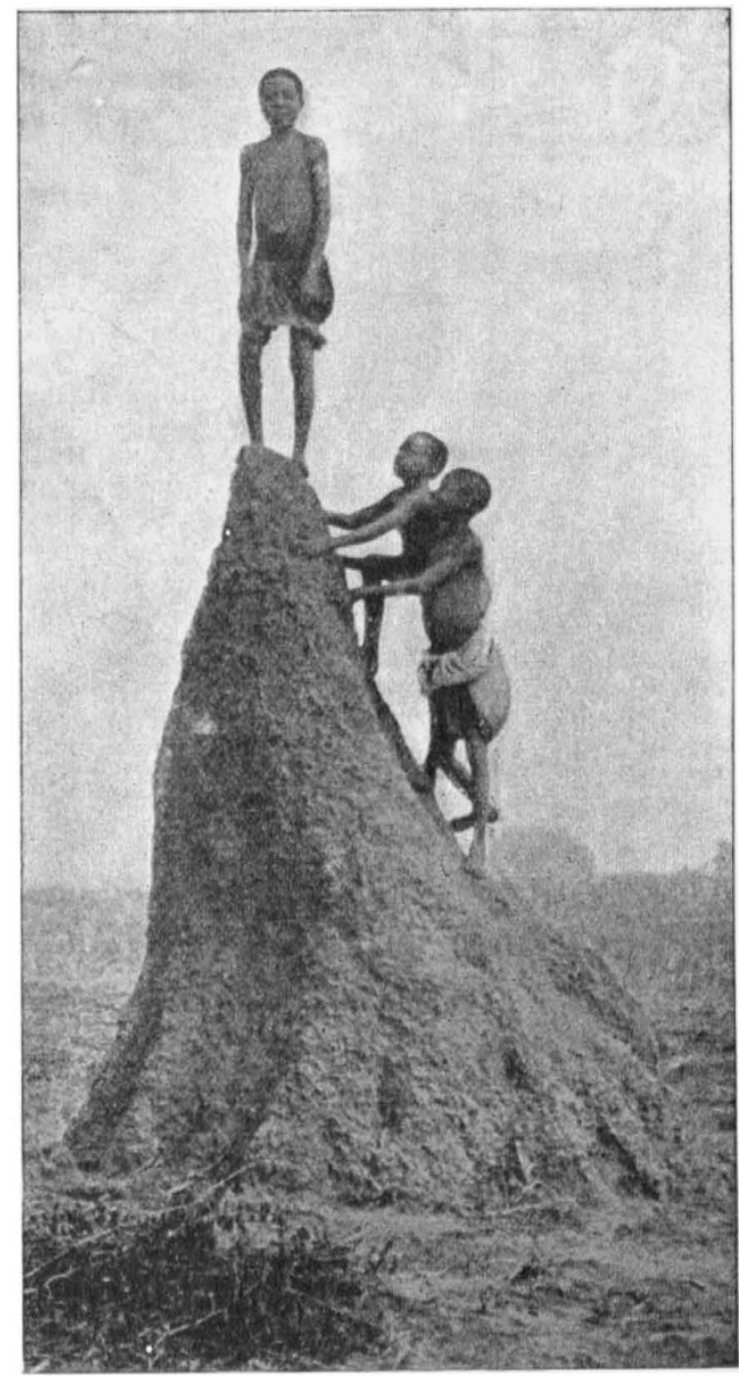

FIG. I. - Boys playing "King of the Castle" on an ant-heap near the Zambezi. From "Savage Childhood," in which the photo. is about an inch lenger and wider than this illustration.

"While English magistrates are above suspicion as to the justness of their decisions from a Western point of view, yet the natives complain not a little concerning the injustice of our government. . . . In olden days no Kafir felt it to be unjust on the part of a chief to make his subjects work for white men, and yet give their money to him (the chief). To Europeans this is essentially unjust, for $1 \mathrm{t}$ is an infringement of the rights of the individual. To the native the rights of the corporate clan are vastly more important than those of the individual. Consequently, when in 
our haste we impose Western conceptions of justice . . on people who are still in the clan-stage of society, our judgments seem to such people absurdly unjust, and even pernicious. . . There are few things the old people grumble about so much as the way the proximity of Europeans, with their new-fangled ideas of justice, undermines the characters of young Kafirs. In olden days there were regular courts of investigation, consisting of a dozen old women of the kraal. All the girls were medically examined by these women before and after large dances; and thus certain forms of vice were impossible as they would be so speedily detected. Nowadays the young women will not submit to such examination, and threaten to complain to the nearest magistrate when it is suggested. Consequently, so the old people say, ancient restraints have been removed, and no new ones have been substituted by white men. The result is disastrous. ...

"The case of 'mixed bathing' of the children is another example of a somewhat similar thing. According to Western conceptions of morality this practice is indelicate and liable to lead to immorality. So missionaries advised natives to abandon it. The natives now declare that the abandonment of this custom has led to an increase of immorality, and say that it introduces new vices amongst the people."

$\mathrm{Mr}$. Kidd is not the only author who has pointed out the injury to health and to morals inflicted on native races by forcing upon them European ideas and customs. People know too little of anthropology and of evolution. They are not aware that the practices, which are as second nature to themselves, have only become so by a course of selective action through thousands of years, and that to force changes on natives whose course of evolution has been so different is almost certain to be disastrous. Changes take time; Nature will not be hurried; and it is particularly necessary to understand, not only the native customs, but the reasons which have determined them. As a contribution to this end, a work with many interesting observations and a considerable array of facts, Mr. Kidd's book may be commended.

\section{ANNIVERSARY MEETING OF THE ROYAL SOCIETY.}

THE anniversary meeting of the Royal Society was held as usual on St. Andrew's Day, November 30 , when the report of the council was presented, the presidential address was read, and the new council already announced ( $p .36$ ) for the ensuing year was elected. The annual dinner was held in the evening at the Hotel Metropole, the chair being taken by Sir William Huggins, K.C.B., in the absence of the president, Lord Rayleigh, owing to illness.

The main features of the activity of the Royal Society during the session $1905^{-6}$ are described in the report of the council. Among other subjects referred to is the preparation of the reports on the scientific results obtained by the late National Antarctic Expedition. The council has decided that these reports shall be published in quarto form, uniform with the Philosophical Transactions and the Challenger publications.

In May last the council learned that the funds $(36,000)$.$) provided by the British South Africa Com-$ pany for the South African meridian arc had been exhausted. The arc had been extended beyond the Zambezi towards Lake Tanganyika, but a gap of 120 miles existed in the middle of it. It was estimated that $r 600 l$. was required to fill this gap, and the matter was most urgent in view of the pending disbandment of the surveying parties. The officers had intimated by authority from the president that the Royal Society would probably be able to subscribe $300 l$. from its private funds on condition that the remainder of the money required were provided; and on the strength of this information, Sir G. Darwin obtained a promise of $800 l$. from the British South Africa Company, Iool. from the Royal Geographical Society, rool. from Wernher, Beit and Co., and cabled to Sir D. Gill that the surveying party was to proceed, thus assuming responsibility for the remaining zool. This $300 l$. has since been subscribed by the British Association from its special South African fund.

The council of the International Association of Academies met in Vienna at the end of May last, Prof. Schuster attending as representative of the Royal Society. Two proposals submitted by the society received considerable support. Regarding one of these, which aims at the establishment of a uniform lunar nomenclature, the council resolved to recommend to the general assembly of the association the appointment of a committee to consider the subject. The proposal that the association should allow itself to be placed at the head of the bodies constituting the International Union for Solar Research was considered, and, while sympathy was expressed with the wishes of the Solar Union, the council felt a difficulty in recommending a scheme that might involve the association in responsibilities which it had no legal power to incur. Prof. Schuster undertook to bring the matter forward again next year in at modified form.

On the suggestion of the Academy of Sciences of Paris, the council agreed to recommend a scheme for the organisation of meteorological stations at different points of the earth's surface.

The subject of international cooperation in the reduction and standardisation of seismological observations has engaged the attention of the council. In accordance with the decision of the International Association of Academies, the proposition made by the German Government and referred to in the last report of the council has, during the present year. been carried into effect. The conditions suggested to the Treasury by the Royal Society, on which the concurrence of this country should be given, have been fulfilled. Both the Governments of France and the Inited States agreed to send representatives to the first meeting of the permanent commission of the International Seismic Association, and on the recommendation of the council Prof. Schuster was deputed by the 'Treasury to attend that meeting as delegate from this country. The various representatives of the different countries which agreed to take part in the operations and deliberations of the commission met in Rome on October 16 last. The chief business of this meeting was the organisation of the work of the association. One of the principal results of the discussion was a resolution to use a portion of the funds at the disposal of the association for the establishment of a seismological station in the Arctic regions. The permanent commission is to meet every two years, and the first general meeting of the association has been arranged to be held next year.

The progress of the Indian magnetic survey, under the direction of Major H. A. D. Fraser, R.E., is reported from time to time to the observatories' committee of the society. Preparations are also in progress for the reduction and publication of the very long serics of magnetic records accumulated at Bombay, under the superintendence of Mr. Moos, the director of the observatory.

A magnetic survey of South Africa has been in progress for some years, under the direction of Prof. 